J. Perinat. Med.

1 (1973) 133

\title{
Diazepam elimination in premature and full term infants, and children
}

\author{
P. L. Morselli, N. Principi, G. Tognoni, E. Reali, G. Belvedere, \\ S. M. Standen, F. Sereni
}

"Istituto di Ricerche Farmacologiche Mario Negri", Milan
and Department of Child Health, University of Milan Medical School

Received September 20, 1972. Accepted October 1, 1972.

In recent years a considerable amount of data have been produced on the activity of the microsomal drug metabolizing systems in the human fetus $[10,16,17,18,19,21,26,29,32]$.

They all indicate that the various metabolic systems responsible for drug degradation are already present in the intrauterine life, though their specific activity is in most cases considerably lower than that of adult standards.

"In vitro" data, while certainly necessary, do not provide an exact index of the rate of "in vivo" metabolism and therefore the information which can be derived is not easily applicable to clinical problems. In fact drug effects are also determined by other factors, such as absorption rate, plasma protein binding, tissue distribution and excretion rate. All these factors vary both with age and physiopathological status [21, 26]. For this reașon studies and observations on newborn infants provide further useful information, which can eventually be applied to everyday practice.

Most of the data currently available on drug kinetics and metabolism in the newborn infant concern antibiotic and sulfonamide compounds $[8,11,23,24,26,27,28]$ though some observations have also been carried out with other drugs $[13,14,21,22,30,31]$. In most. cases they indicate a slower disposition of the drug as compared to children.

No data on the metabolic disposition of benzodiazepines in the newborn infant have been available up to now, despite the fact that this class of drug is widely administered during

\section{Curriculum vitae}

P. L. Morselli, was born in Bergamo (Italy) 1937. He obtained his degree as M. D. at Milano University in 1961. His main research interests are in Clinical Pharmacology.

From 1965 to 1967 be was a Fullbright Scholar and a Research Fellow in pharmacology at the Medical College of Virginia University, USA. From 1968 to 1969 be was a Merck Sharp \& Dobme's Fellow in Clinical Pharmacology'. Since 1968 Dr. MORSELLI has been bead of the Laboratory of Clinical Pharmacology of the "Istituto di Ricerche Farmacologiche Mario Negri", Milan.

He is author of more than 40 publications mainly dealing with psychotropic drug metabolism in bumans, relationsbips between drug plasma levels and therapeutic and side effert.r and drug interactions.

gestation and labor $[3,15]$, and in the first days of extrauterine life to control seizures [20]. In the present report we will describe some observations we were able to make on premature infants, full-term infants and children who received diazepam for therapeutic reasons. In adult subjects diazepam undergoes metabolic demethylation, and hydroxylation, and it is excreted mainly as conjugated derivatives $[2,4,6,25]$. Evidence will be presented that in premature infants as well as in full-term newborns there is a reduced capability to hydroxylate diazepam 


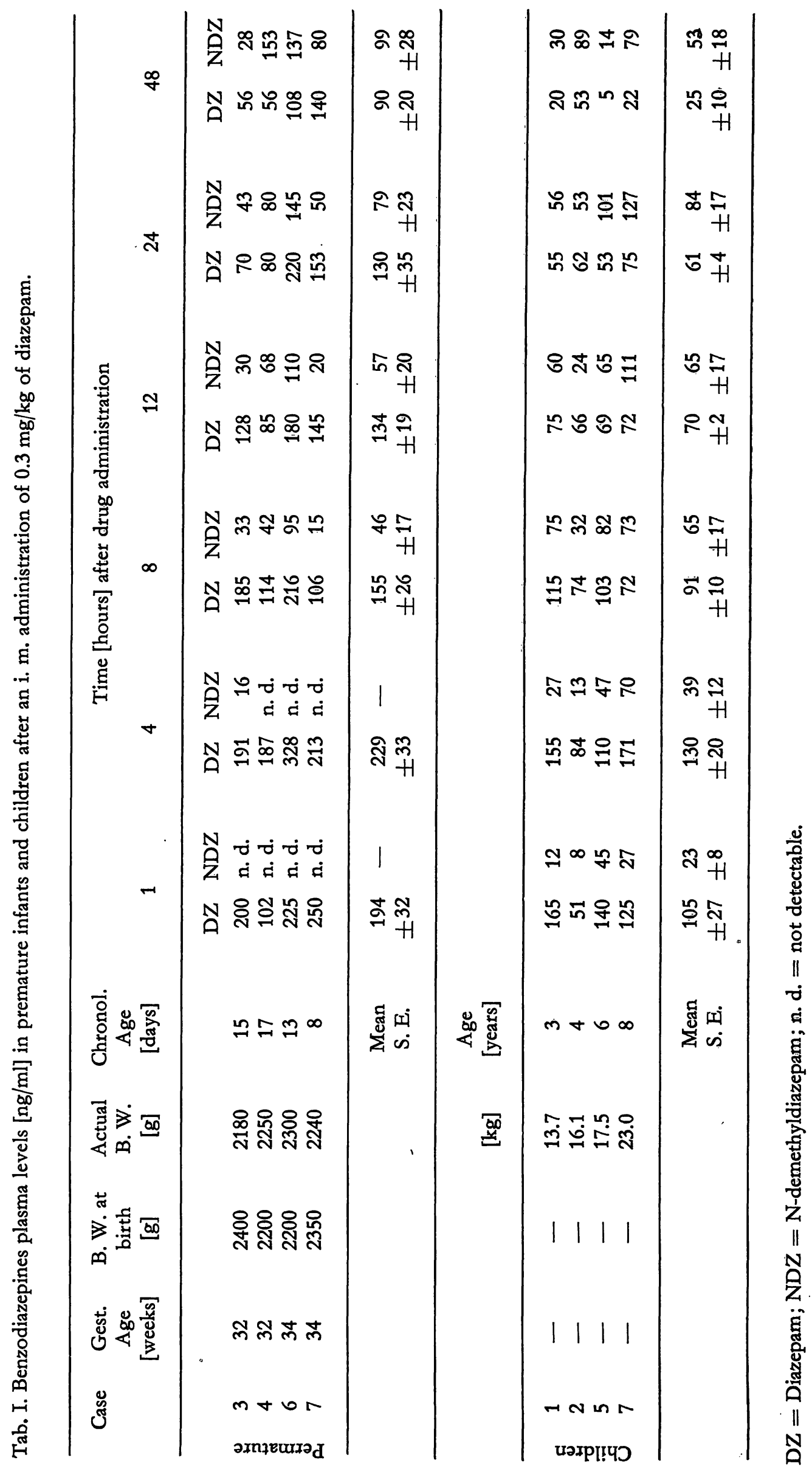


as well as a reduced excretion of conjugated derivatives.

\section{Subjects, materials and methods}

\subsection{Subjects}

All patients studied had to receive benzodiazepine to control seizure disorders or behavioural disturbances. The observations were carried out on three groups of patients:

-9 premature infants. 8-81 days old (gestational age 28-34 weeks) 8 full-term infants 4-162 days old, 7 children 3 to 7 years old. In all patients clinical laboratory tests were within normal limits for liver functions.

Diazepam (Valium ${ }^{\circledR}$ ROCHE) was administered i. $m$. at the therapeutic dose of $0.3 \mathrm{mg} / \mathrm{kg}$ using a HAMILTON-BONADUR Schweiz microsyringe.

\subsection{Blood sampling and urine collection}

From 4 prematures and 4 children it was possible to collect heparinized venous blood samples $(1-1.5 \mathrm{ml})$ at various times before and after administration (Tab. I).

Fractionated 24 hour urine samples were collected whenever possible in all the three groups (premature infants, fullterm infants and children). Blood samples were centrifuged within 30 minutes and the plasma so obtained kept frozen at $20^{\circ} \mathrm{C}$ until analyzed for benzodiazepine content. Similarly samples of urine were frozen after collection and kept at $20^{\circ} \mathrm{C}$ until analyzed.

\subsection{Chemical analysis}

Determination of diazepam (DZ), N-demethyldiazepam $(\mathrm{NDZ})$ and oxazepam (OX) was carried out on $0.2-0.4 \mathrm{ml}$ of plasma and on 5-10 ml of urine according to GaratrinI et al. [5] with some modifications as described below.

\subsubsection{Extraction from plasma}

$0.2-0.4 \mathrm{ml}$ of plasma buffered with $1 \mathrm{ml}$ of phosphate buffer ( $\mathrm{pH}$ 7) was extracted three times with $4 \mathrm{ml}$ of diethyl ether. $10 \mathrm{ml}$ of the organic combined fraction was then back-extracted with $3 \mathrm{ml}$ of $1 \mathrm{~N} \mathrm{HCl}$. The acqueous phase was washed twice with $5 \mathrm{ml}$ of diethyl ether and alkalinized to $\mathrm{pH} \mathrm{9-10} \mathrm{with} 0.7 \mathrm{ml}$ of $6 \mathrm{~N} \mathrm{NaOH}$. The alkalinized acqueous fraction was then extracted three times with $5 \mathrm{ml}$ of diethyl ether and $14 \mathrm{ml}$ of the organic phase was dried out in a water-bath at $40^{\circ} \mathrm{C}$ in a finely tapered test tube. The drug residue was then redissolved in $50 \mu \mathrm{l}$ of acetone containing 2-N-benzylamino-5-chloru-benzophenone $(5 \mu \mathrm{g} / \mathrm{ml})$ as internal marker. $1-2 \mu \mathrm{l}$ of this solution was used for GLC determination.

\subsubsection{Extraction from urine}

$5 \mathrm{ml}$ of urine was buffered with $3 \mathrm{ml}$ of phosphate buffer $(\mathrm{pH} 7)$ and extracted three times with $5 \mathrm{ml}$ of diethyl ether. $12 \mathrm{ml}$ of the organic phase were then processed as des- cribed for plasma, and the remaining acqueous phase used for determination of conjugated compounds.

\subsubsection{Extraction of conjugated compounds from urine}

After extraction with ether at $\mathrm{pH} 7$, the acqueous phase was acidified to $\mathrm{pH} 5$ with $0.5 \mathrm{ml}$ of $6 \mathrm{~N} \mathrm{HCl}$ and $2.5 \mathrm{ml}$ of acetate buffer $(\mathrm{pH} 5)$ and incubated overnight at $37^{\circ} \mathrm{C}$ with $5 \times 10^{3}$ units of $\beta$-glucuronidase. The urine was then alkalinized to $\mathrm{pH} 9-10$ with $6 \mathrm{~N} \mathrm{NaOH}$ and extracted three times with $5 \mathrm{ml}$ of diethyl ether. $14 \mathrm{ml}$ of the organic phase were then dried and processed as before. Determinations of N-Methyloxazepam (MeOX) were performed on $0.1 \mathrm{ml}$ of plasma and $5 \mathrm{ml}$ of urine according to the recently described procedure of BELVEDERE et al. [1]. This procedure is based on the conversion of $\mathrm{N}$ Methyloxazepam to its TMS derivative and leads to. improved sensitivity. The identity of the compounds was. checked by TLC ( $\mathrm{CH} \mathrm{Cl}_{3}$-Acetone 9:1) and by combined gaschromatography-mass-spectrometry against known reference standards.

\subsection{Apparatus}

A Carlo Erba Fractovap Model G 1, gaschromatograph, equipped with 63 Mi ECD was used.

Diazepam, N-demethyldiazepam and oxazepam determinations were performed on a glass column $2 \mathrm{~m}$ long, $4 \mathrm{~mm}$ i. d., packed with 3\% OV 17 on Gaschrom Q (Applied Science Lab.) operated at the following temperatures: oven $270^{\circ} \mathrm{C}$, injector $280^{\circ} \mathrm{C}$, detector $285^{\circ} \mathrm{C}$. Carrier gas. flow (Nitrogen) $40 \mathrm{ml} / \mathrm{min}$.; scavenger gas flow (Nitrogen). $70 \mathrm{ml} / \mathrm{min}$. N-Methyloxazepam determinations were carried. out on a glass column $1 \mathrm{~m}$ long, $4 \mathrm{~mm}$ i. d., packed as. before and operated at the following temperatures: oven $220^{\circ} \mathrm{C}$, injector $240^{\circ} \mathrm{C}$, detector $250^{\circ} \mathrm{C}$. Carrier and scavenger gas flow $50 \mathrm{ml} / \mathrm{min}$. An LKB 9000 gaschromatographmass-spectrometer was used for mass analysis.

\subsection{Statistical analysis}

Owing to the small number of blood samples taken, it was not possible to calculate individual kinetics for the data in Tab. I. However, a regression analysis on the logarithms of the combined diazepam plasma concentrations showed that the means at $8,12,24$ and 48 hours could be considered to be linearly related for both premature infants and children.

The slope of the regression line, is proportional to the average pharmacokinetic elimination constant, Kel. This Kel may be considered as the "body elimination rate" (Grbaldi et al. [7]) and is related to the apparent body half life of the drug, $\mathrm{T}^{1} / 2$; the volume of distribution $(\mathrm{Vd})$ was. calculated according to GibaLdr et al. [7]. 
A Student's t-test was used to test the significance of the difference between the slopes of the two regression lines. The results of this significance test extend to cover differences between the body elimination rates and the apparent body half lives. Comparisons between means score was made using Student's t-test.

\section{Results}

2.1 Plasma levels of diazepam and of its metabolites in premature infants and children

As mentioned above in "methods" we were able to follow up individual plasma levels of diazepam and of its metabolites after a single intramuscular administration in 4 premature infants (cases No. 3, 4, 6, 7) and in 4 children (cases No. 1, 2, 5, 7).

Results summarized in Tab. I show noticeable individual differences in both groups. The diazepam plasma levels tended to be higher and longer lasting in the premature infants than in the children. Mean values in the premature infants after 24 and 48 hours were roughly double those in the children.

Since for ethical reasons it was not possible to collect enough samples to allow calculation of individual kinetics, the results in Tab. II are based on combined data for each of the two groups. As reported in Tab. II significant differences were observed.

Tab. II. Apparent pharmacokinetic constants of diazepam in permature infants and children.

\begin{tabular}{lccc}
\hline & $\mathrm{Kel}\left(\mathrm{hr}^{-1}\right)$ & $\mathrm{App} \mathrm{T}{ }^{1 / 2}$ & $\mathrm{Vd}(\mathrm{l} / \mathrm{kg})$ \\
\hline Prematures & $0.013 * *$ & $54 * *$ & 1.10 \\
Children & 0.038 & 18 & 1.99 \\
\hline
\end{tabular}

$* *=\mathrm{P}<0.05$ in respect to children group.

The premature group showed a $\mathrm{Kel}$ of 0.013 with an apparent plasma half-life of 54 hours, while the children had a Kel of 0.038 and an apparent plasma half-life of 18 hours $(P<0.05$ for this difference). Differences were also present in the volume of distribution.

With regard to the diazepam metabolites no $\mathrm{N}$ methyloxazepam or oxazepam could be detected in plasma of either group. N-demethyldiazepam, on the contrary, was found in measurable amounts both in prematures and children. Even so, appreciable differences were observed.

While in all the four children studied N-demethyl diazepam was already present in measurable amounts 1 hour after drug administration, in the premature infants the compound was measurable only after 8 hours in 3 out of 4 cases. These data suggest a slower demethylation process in premature infants. It is also interesting that while for the children in 3 out of 4 cases the $\mathrm{N}$-demethyldiazepam levels tended to decline after 24 hours, for the premature group in 3 out of 4 cases the $\mathrm{N}$-demethyldiazepam levels were still increasing after 48 hours. These data suggest a reduced breakdown of the demethylated metabolite.

2.2 24-hour urinary excretion of diazepam and of its metabolites in premature infants and children

The 24-hour urinary excretion of diazepam and its metabolites was followed up in 7 premature infants (cases No.1, 2, 5, 6, 7, 8, 9), 8 full term infants (cases No.1, 2, 3, 4, 5, 6, 7, 8), and 5 children (cases No. 2, 3, 4, 5, 6). The 24-hour urinary excretion of unconjugated benzodiazepines (Diazepam and N-demethyldiazepam) was found to be very small (Tab. III) and no

Tab. III. Mean values of the 24 hour urinary excretion of unconjugated benzodiazepines in premature infants, fullterm infants and children following an i.m. administration of $0.3 \mathrm{mg} / \mathrm{kg}$ of diazepam.

\begin{tabular}{lrrr}
\hline & \multicolumn{3}{c}{ Unconjugated Benzodiazepines } \\
& $\mathrm{DZ}$ & $\mathrm{NDZ}$ & \multicolumn{1}{c}{ Total } \\
\hline Premature & 0.053 & 0.057 & 0.110 \\
& \pm 0.010 & \pm 0.020 & \pm 0.022 \\
Fullterm & 0.052 & 0.174 & 0.226 \\
& \pm 0.022 & \pm 0.048 & \pm 0.053 \\
Children & 0.017 & 0.054 & 0.071 \\
& \pm 0.006 & \pm 0.012 & \pm 0.013 \\
\hline
\end{tabular}

Values are expressed as $\%$ of the administered dose. 
significant differences were noticed among the three groups.

Analysis of ethereal extracts of urine incubated with $\beta$-glucuronidase showed the following three compounds to be present: $\mathbf{N}$-demethyldiazepam, $\mathrm{N}$-methyloxazepam and oxazepam. There were significant differences between the three age groups (Tab. IV).

Tab. IV. Mean values of the 24 hour urinary excretion of conjugated benzodiazepines in permature infants, full term infants and children following an i. m. administration of $0.3 \mathrm{mg} / \mathrm{kg}$ of diazepam.

\begin{tabular}{lcc}
\hline & \multicolumn{2}{c}{ Total conjugated Benzodiazepines } \\
\hline Premature & $0.987 \pm 0.434$ & $(\mathrm{P}<0.01)^{*}$ \\
Fullterm & $1.418 \pm 0.453$ & $(\mathrm{P}<0.05)^{*}$ \\
Children & $4.377 \pm 1.007$ & \\
\hline
\end{tabular}

Values are expressed as $\%$ of the administered dose

$*=$ with respect to children.
The total amount of benzodiazepine excreted as conjugated compounds in the first 24 hours following drug administration was higher in children than in full-term infants $(P<0.05)$ or in premature infants $(P<0.01)$.

This picture becomes more interesting when we consider the single metabolic products and their ratios. In fact, as reported in Tab. V, although $\mathrm{N}$-demethyldiazepam was present in equivalent amounts in all the groups, marked differences were observed with regard to the hydroxylated metabolites (N-methyloxazepam and oxazepam). In the premature group no hydroxylated compounds were detectable even in the 81 day-old subject (case 9). In the full-term group, hydroxylated compounds were absent or present in unmeasurable amounts up to 10 days of age, while they were constantly present in subjects over 2-3 weeks of age.

Tab. V. 24 hour urinary excretion of diazepam metabolites in premature infants, full term infants and children after an i. $\mathrm{m}$. administration of $0.3 \mathrm{mg} / \mathrm{kg}$ of diazepam.

\begin{tabular}{|c|c|c|c|c|c|c|c|c|}
\hline & Case & Age* & $\begin{array}{l}\text { B. W. } \\
{[\mathrm{kg}]}\end{array}$ & $\begin{array}{c}24 \mathrm{~h} \\
\text { Urine } \\
{[\mathrm{ml}]}\end{array}$ & $\begin{array}{l}\text { NDZ } \\
{[\%}\end{array}$ & $\begin{array}{l}\text { MeOX } \\
\text { Iminister }\end{array}$ & $\begin{array}{l}\text { OX } \\
\text { e] }\end{array}$ & $\begin{array}{c}\text { Total } \\
\text { conjugated } \\
\text { [\% of } \\
\text { admi- } \\
\text { nistered } \\
\text { dose] }\end{array}$ \\
\hline 幽 & $\begin{array}{l}1 \\
2 \\
5 \\
6 \\
7 \\
8 \\
9\end{array}$ & $\begin{array}{r}8 \mathrm{~d}(28 w) \\
15 \mathrm{~d}(32 \mathrm{w}) \\
17 \mathrm{~d}(32 \mathrm{w}) \\
13 \mathrm{~d}(34 \mathrm{w}) \\
8 \mathrm{~d}(34 \mathrm{w}) \\
21 \mathrm{~d}(34 \mathrm{w}) \\
81 \mathrm{~d}(32 \mathrm{w})\end{array}$ & $\begin{array}{l}2.1 \\
2.1 \\
2.2 \\
2.3 \\
2.2 \\
2.1 \\
2.9\end{array}$ & $\begin{array}{r}315 \\
150 \\
\cdot 101 \\
170 \\
238 \\
240 \\
188\end{array}$ & $\begin{array}{l}0.96 \\
0.36 \\
0.19 \\
0.74 \\
0.54 \\
0.67 \\
3.52\end{array}$ & $\begin{array}{l}\text { n. d. } \\
\text { n.d. } \\
\text { n.d. } \\
\text { n.d. } \\
\text { n.d. } \\
\text { n.d. } \\
\text { n.d. }\end{array}$ & $\begin{array}{l}\text { n. d. } \\
\text { n.d. } \\
\text { n.d. } \\
\text { n.d. } \\
\text { n. d. } \\
\text { n.d. } \\
\text { n.d. }\end{array}$ & $\begin{array}{l}0.96 \\
0.36 \\
0.19 \\
0.74 \\
0.54 \\
0.67 \\
3.52\end{array}$ \\
\hline 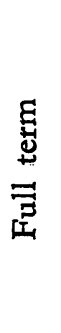 & $\begin{array}{l}1 \\
2 \\
3 \\
4 \\
5 \\
6 \\
7 \\
8\end{array}$ & $\begin{array}{l}4 \mathrm{~d} . \\
4 \mathrm{~d} . \\
10 \mathrm{~d} . \\
18 \mathrm{~d} . \\
30 \mathrm{~d} . \\
96 \mathrm{~d} . \\
143 \mathrm{~d} . \\
162 \mathrm{~d} .\end{array}$ & $\begin{array}{l}3.1 \\
3.2 \\
3.3 \\
3.4 \\
3.1 \\
4.2 \\
5.1 \\
4.8\end{array}$ & $\begin{array}{l}113 \\
216 \\
185 \\
225 \\
147 \\
130 \\
285 \\
244\end{array}$ & $\begin{array}{l}0.23 \\
0.46 \\
0.86 \\
1.46 \\
0.38 \\
1.50 \\
0.50 \\
0.75\end{array}$ & $\begin{array}{c}\text { traces } \\
\text { n. } d . \\
\text { traces } \\
0.48 \\
0.12 \\
2.52 \\
0.40 \\
0.98\end{array}$ & $\begin{array}{l}\text { n. d. } \\
\text { n. d. } \\
\text { n.d. } \\
\text { traces } \\
0.07 \\
0.01 \\
0.01 \\
0.57\end{array}$ & $\begin{array}{l}0.23 \\
0.46 \\
0.86 \\
1.94 \\
0.58 \\
4.06 \\
0.92 \\
2.30\end{array}$ \\
\hline 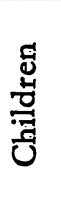 & $\begin{array}{l}2 \\
3 \\
4 \\
5 \\
6\end{array}$ & $\begin{array}{l}4 \mathrm{y} . \\
5 \mathrm{y} . \\
5 \mathrm{y} . \\
6 \mathrm{y} . \\
7 \mathrm{y} .\end{array}$ & $\begin{array}{l}16.1 \\
20.0 \\
14.0 \\
17.5 \\
18.0\end{array}$ & $\begin{array}{l}215 \\
410 \\
615 \\
500 \\
840\end{array}$ & $\begin{array}{l}0.99 \\
0.81 \\
1.87 \\
2.69 \\
0.98\end{array}$ & $\begin{array}{l}0.70 \\
1.52 \\
2.12 \\
1.14 \\
0.86\end{array}$ & $\begin{array}{l}2.00 \\
0.53 \\
1.23 \\
4.34 \\
0.76\end{array}$ & $\begin{array}{l}3.71 \\
2.90 \\
4.61 \\
8.23 \\
2.69\end{array}$ \\
\hline
\end{tabular}

* = For premature infants the gestational age at birth is reported in parentheses.

n. d. = not detectable. The sensitivity of the method allows determinations of urine concentrations as low as $0.15 \mathrm{ng} / \mathrm{ml}$ for MeOX and $0.30 \mathrm{ng} / \mathrm{ml}$ for OX. 
Tab. VI. Ratio* between hydroxylated and non-hydroxylated benzodiazepines present in the 24 hour urine of premature infants, fullterm infants and children after diazepam administration $(0.3 \mathrm{mg} / \mathrm{kg}$ i. $\mathrm{m}$.)

\begin{tabular}{cccccc}
\hline \multicolumn{2}{c}{ Premature infants } & \multicolumn{2}{c}{ Fullterm infants } & \multicolumn{2}{c}{ Children } \\
\hline Gest. age & Ratio & [Age days] & Ratio & [Age years] & Ratio \\
[weeks] & - & 4 & - & 4 & 2.67 \\
28 & - & 4 & - & 5 & 2.41 \\
32 & - & 10 & - & 5 & 2.66 \\
32 & - & 18 & 0.24 & 6 & 1.99 \\
34 & - & 96 & 0.40 & 7 & 1.52 \\
34 & - & 143 & 1.27 & & \\
34 & 162 & 1.73 & & \\
32 & & & & & \\
\hline
\end{tabular}

$*=\frac{(\mathrm{MOX})+(\mathrm{OX})}{(\mathrm{DZ})+(\mathrm{NDZ})}$ in 24 hour urine.

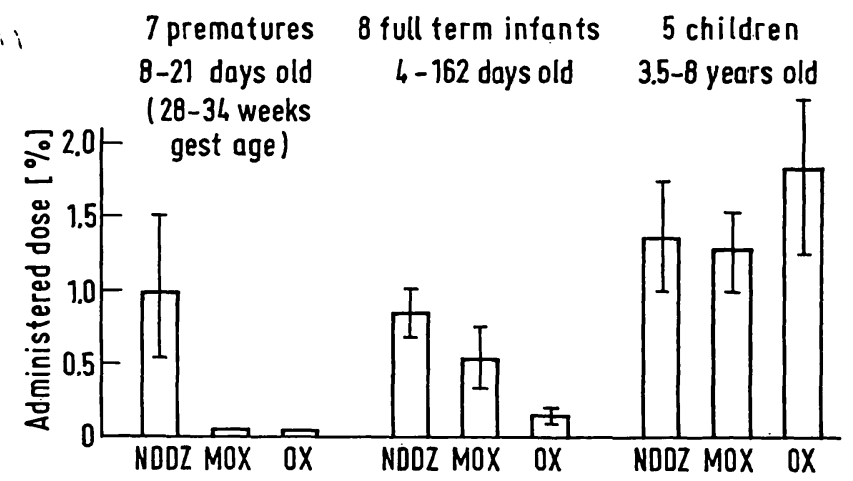

Fig. 1. 24 hour urinary excretion of diazepam metabolites after a single i. m. administration of $0.3 \mathrm{mg} / \mathrm{kg}$ of diazepam

However, mean values were lower when compared to the children (Fig. 1). The difference was more marked for oxazepam than for N-methyloxazepam. If we consider the ratios between the hydroxylated derivatives and the non-hydroxylated ones, we can see (Tab. VI) that only in the 5 month-old infant is the ratio of the same magnitude as that observed in fully grown children.

\section{Discussion}

After administration of a single pro kilo dose of the drug, premature infants tended to have higher and more persistent plasma levels of diazepam in comparison to the children. The apparent plasma disappearance rate was significantly prolonged in the premature group suggesting a reduced capability of the processes responsible for molecule breakdown and elimination. Other factors may however play an important role in determining this phenomenon. Diazepam is known to accumulate in considerable amounts in the adipose tissue of animals and humans $[6,12]$. A different binding of diazepam to various tissue components or a reduced amount of adipose tissue could in part explain the higher levels of diazepam observed in premature infants. In fact a considerable difference in distribution of volume was observed in our cases. The rate of formation of N-demethyldiazepam was slower in prematures than in children suggesting that the total capacity of the demethylating system is comparatively reduced in the first group.

Furthermore that the tendency to accumulate Ndemethyldiazepam with high -levels persists even after 48 hours suggests that hydroxylation processes are likewise inefficient in the premature. This hypothesis is further sustained by the urinary data. No hydroxylated compounds could in fact be detected in the urine of premature infants and the same was observed in full-term infants less than two weeks old. The total conjugated benzodiazepines present in the 24 hour urine were also lower in premature and full term infants than in children. Other authors $[9,21]$ have described the presence of hydroxylated compounds in the urine of newborns after drug administration to the mother.r However no attempt was really made to clarify whether the hydroxylated compounds were derived from the mother or were inherent in the newborn metabolism. 
A reduced drug metabolizing activity in the premature and newborn is further supported by preliminary observations [26] in which diazepam and its metabolites were followed up in newborns whose mothers had been exposed to benzodiazepine treatment before the delivery.

It was seen that both diazepam and $\mathbf{N}$-demethyldiazepam crossed the placenta and both accumulated in the fetus. The plasma concentrations of diazepam and $\mathrm{N}$-demethyldiazepam were quite constant during the first 48-72 hours of extra-uterine life, suggesting a reduced capacity in the newborn to further metabolize the drugs.

In conclusion it appears from our data that newborn infants, both premature and full term, have a limited capacity for metabolizing and excreting drugs. It also seems likely that the degree of limitation of the various drug

\section{Summary}

Benzodiazepines are often used during labor, and they are also frequently administered to newborns in cases of seizure. In adults this class of drug requires an extensive metabolization in order to be eliminated.

The physiological elimination of diazepam administered at the dose of $0.3 \mathrm{mg} / \mathrm{kg}$ by intramuscular route (Tab. I), was followed up in three groups of subjects (premature infants, full-term infants and children). Plasma levels of diazepam (DZ) and of its major metabolite $\mathrm{N}$-demethyldiazepam (NDZ) could be followed up for 48 hours after drug administration in 4 premature infants and 4 children.

24 hour urinary excretion of DZ, NDZ, N-Methyloxazepam (MeOX) and Oxazepam (OX) was followed up in 7 premature infants, 8 full term infants and 5 children.

Determination of benzodiazepine compounds both in plasma and urine, was performed, after etheral extraction, by GLC-ECD. In the urine samples free and conjugated compounds were measured (Tab. III).

The apparent disappearance rate of diazepam plasma was significantly reduced $(P<0.05)$ in premature infants $\left(\mathrm{T}^{1} / 2=58 \mathrm{hrs}\right)$ when compared to that of the children $(\mathrm{T} / 2=18 \mathrm{hrs})$.

Keywords: Diazepam, physiological elimination, metabolism, premature infants, full term infants, children, plasma levels, urinary excretion.

\section{Zusammenfassung}

Diazepam-Ausscheidung bei Frühgeborenen und reifen Neugeborenen sowie älteren Säuglingen

Benzodiazepine werden oft während der Geburt verabreicht und auch häufig Neugeborenen gegeben, wenn sie Krampfanfälle bekommen. Bei Erwachsenen benötigt dieses Medikament einen komplizierten Abbau, bevor es ausgeschieden werden kann. metabolizing systems is not uniform, and different results may also be obtained with other substrates. From a practical point of view, a limited metabolizing and excreting activity implies a longer persistence of pharmacologically active substances in the neonatal body fluids and tissues, and consequently prolonged pharmacological effects. The clinical implications of this phenomenon are almost completely unknown. Although our findings cannot establish the optimal dosage regimen of diazepam, they suggest that the drug should be used in premature and full term infants at lower doses than in children. More data are needed on the metabolism of drugs in newborns and infants as the necessary premise to a more integrated approach, both pharmacological and clinical, to the problem of drug dosage in newborn infants.

The rate of formation of $\mathbf{N}$-demethyldiazepam was slower in prematures than in children.

A difference in the distribution of volume was also noticed. The urinary data further supported reduced $D Z$ elimination in the premature infants and fullterm infants. No hydroxylated derivatives ( $\mathrm{MeOX}$ and $\mathrm{OX}$ ) were in fact found in the urine of premature infants nor in the urine of full-term infants up of 10 days of age.

On the contrary the hydroxylated compounds ( $\mathrm{MeOX}$ and $\mathrm{OX}$ ) represented the major portion of diazepam metabolites present in the urine of children.

The data indicate that in the newborn (either premature or full term) the physiological elimination of diazepam is markedly reduced when compared to children.

This is probably du: to a limited capacity to form $\mathbf{N}$ demethylated and hydroxylated derivatives which are subsequently excreted as such or as conjugated compounds. A prolonged persistence of diazepam and of its $\mathrm{N}$ demethylderivative (which still retains pharmacological activity) in the biological fluids and tissues has to be taken into account when this drug is administered to newborns.
Der Abbau des Diazepam, intramuskulär injiziert in einer Menge von $0.3 \mathrm{mg} / \mathrm{kg}$, wurde verfolgt in drei Gruppen (Frühgeborene, Termingeborene und ältere Säuglinge). Die Konzentration des Diazepam und seines wichtigsten Stoffwechselprodukts, N-Demethyldiazepam (NDZ) im Plasma wurde während 48 Stunden gemessen bei 4 Frühgeborenen und 4 Säuglingen. Die Ausscheidung von $\mathrm{DZ}, \mathrm{NDZ}, \mathrm{N}$-Methyloxazepam (MeOX) und Oxa- 
zepam (OX) wurde im Urin 7 Frühgeborener, 8 reifer Neugeborener und 5 Kinder 24 Stunden lang verfolgt. Nach Ätherextraktion mit GLC-ECD wurden die Benzodiazepin-Verbindungen im Plasma und Urin bestimmt. Im Urin haben wir auch die freien und konjugierten Substanzen gemessen.

Unsere Untersuchungen ergaben, daß Diazepam wesentlich langsamer aus dem Plasma verschwindet $(P<$ 0.05 , wenn das Kind $\mathrm{zu}$ früh geboren wurde $\left(\mathrm{T}^{1} / 2=\right.$ 58 Stunden bei Frühgeborenen und $\mathrm{T}^{1} / 2=18$ Stunden für ältere Kinder). N-Demethyldiazepam wurde entsprechend langsamer produziert in diesen Frühgeborenen. Ein Unterschied in der Menge der Verteilung konnte auch beobachtet werden. Die Ergebnisse der Urinuntersuchung unterstützten auch die Beobachtung einer verminderten DZ-Ausscheidung bei Frühgeborenen und Termingebore- nen. In der Tat wurden keinerlei Hydroxylderivate (MeOX und OX) im Urin Frühgeborener oder anderer Neugeborener vor dem zehnten Lebenstag gefunden. Andrerseits waren diese Hydroxylderivate die Hauptportion der DZ-Stoffwechselprodukte im Urin älterer Säuglinge.

Diese Ergebnisse zeigen, daß beim Neugeborenen die physiologische Ausscheidung des Diazepam wesentlich reduziert ist. Dies stellt wahrscheinlich eine verminderte Fähigkeit dar, N-Demethyl und Hydroxylderivate zu bilden, die nachher als solche oder als konjugierte Substanzen ausgeschieden werden. Diazepam und sein $\mathrm{N}$ Demethylderivat bleiben daher länger in den biologischen Flüssigkeiten und Geweben, wo sie weiterhin ihre pharmakologische Tätigkeit ausüben.

Schlüsselwörter: Diazepam, Ausscheidung, Stoffwechsel, Frühgeborene, Reife Neugeborene, Säuglinge, Plasma-Konzentration, Urinausscheidung.

\section{Résumé \\ Métabolisme du Diazepam chez le nouveau-né pré- maturé et à terme et chez l'enfant}

Les benzodiazepines sont souvent employées au cours du travail, et elles sont aussi fréquemment administrées au nouveau-né en cas de convulsions. Chez l'adulte, ce type de produit doit subir des modifications métaboliques importantes pour être éliminé.

Le métabolisme du diazepam, administré à la dose de $0,3 \mathrm{mg} / \mathrm{kg}$ par voie intra-musculaire, a été étudié pour trois groupes de sujets (prématurés, noúveau-nés à terme et enfants). Le taux de diazepam (DZ) plasmatique et de son principal métabolite $\mathrm{N}$-demethyldiazepam (NDZ) a pu être suivi pendant 48 heures après l'administration du médicament chez quatre prématurés et quatre enfants.

L'excrétion urinaire de 24 heures de $\mathrm{DZ}, \mathrm{NDZ}, \mathrm{N}$ Méthyloxazepam (MeOX) et Oxazepam (OX) a été suivie chez 7 prématurés, 8 nouveau-nés à terme et 5 enfants.

La mesure des composés benzodiazepiniques dans le plasma et dans l'urine a été réalisée, après extraction par l'éther, par «GLC-ECD». Dans les échantillons d'urine on a mesuré les composants libres et conjugés. La vitesse de disparition apparente du diazepam plasmatique était réduite de façon significative $(P<0.05)$ chez les prématurés $\left(T^{1} / 2=58 \mathrm{~h}\right.$ ) par rapport à celle dẹs enfants $\left(\mathrm{T}^{1} / 2=18 \mathrm{~h}\right)$.

La vitesse de formation du $\mathbf{N}$-demethyldiazepam était chez les prématurés inférieure à celle des enfants. On a aussi noté une différence dans le vclume de distribution. Les résultats des dosages urinaires étaient très en faveur d'une diminution d'excrétion de $\mathrm{DZ}$ chez les prématurés et chez les nouveau-nés à termè. On n'a pas mis en évidence de dérivés hydroxylés ( $\mathrm{MeOX}$ et $\mathrm{OX}$ ) dans les urines des prématurés ni dans les urines des enfants nés à terme jusqu'à 10 jours d'âge.

$\mathrm{Au}$ contraire, les composés hydroxylés ( $\mathrm{MeOX}$ et $\mathrm{OX}$ ) représentaient la majeure partie des métabolites présents dans l'urine des enfants. Ces résultats indiquent que chez le nouveau-né le métabolisme du diazepam est nettement réduit, par rapport à celui de l'enfant.

Ceci est probablement dû à la capacité limitée de former des dérivés $\mathbf{N}$-demethylés et hydroxylés qui sont ensuite excrétés sous cette forme ou sous forme conjuguée. La persistance prolongée de diazepam et de ses dérivés $\mathrm{N}$-demethylés (qui gardent une activité pharmacologique) dans les liquides biologiques et les tissus, doit être prise en considération lorsqu'on administre cette drogue aux nouveau-nés.

Mots-clés: Diazepam, métabolisme, prématuré, nouveau-né à terme, enfant, taux plasmatique, excrétion urinaire.

\section{Acknowledgement}

This work was parrially supported by NIH Grant 1-PO1-GM-18376-01-PTR and by CNR Grant 70.01184. 04. 115.4019. The technical assistance of Miss. L. ZanzotTERA is greatly appreciated.

\section{Bibliography}

[1] Belvedere, G., G. Tognoni, A. Frigerio, P. L. MorSElli: A specific, rapid and sensitive method for gaschromatographic determination of methyloxazepam in small samples of blood. Analyt. Letters 5 (1972) 531
[2] DE Silva, A., B. A. Koechlin, G. Bader: Blood level distribution pattern of diazepam and its major metabolite in man. J. pharm. Sci. 55 (1966) 692

[3] Flowers, G. C., F. A. J. Rudolph, M. M. Desmond: Diazepam (Valium $($ ) as an adjunct in obstetric analgesia. Obstet. Gynec. 34 (1969) 68 
[4] Garattini, S.: Metabolism of diazepam in animals and man. In: Cerlettr, A., F. J. Bove: The Present Status of Psychotropic Drugs, Excerpta Medica Foundation, Amsterdam 1969

[5] Garatinini, S., F. Marcucci, E. Mussini: Gaschromatographic analysis of benzodiazepines. In: PORTER, R.: Gas-chromatography in Biology and Medicine, J. A. Churchill, London 1969

[6] Garatinni, S., F. Marcucci, P. L. Morselli, E. Mussinr: The significance of measuring blood levels of benzodiazepines. In: Proceedings Symposium British Pharmacological Society, London 1972, in press

[7] Grbaldi, M., R. Nagashima, G. Levy: Relationship between drug concentrations in plasma or serum and amount of drug in the body. J. pharm. Sci. 58 (1969) 193

[8] Gladtke, E.: Pharmakokinetik von Chemotherapeutica in Abhängigkeit vom Lebensalter. Mschr. Kinderheilk. 119 (1971) 105

[9] Horning, M. G., D. Harvex, E. C. Horning, R. M. HILL: GCMS study of drug metabolites resulting from the expoide-diol pathway. In: Frigerio, A.: Proceedings of International Symposium on Gas Chromatography-Mass Spectrometry. Tamburini Publisher, Milano 1972

[10] IDÄNPÄÄN-HeIkkIlA, J. E., P. J. JouppIlA, J. O. Puolakka, M. S. Vorne: Placental transfer and fetal metabolism of diazepam in eraly human pregnancy. Amer. J. Obstet. Gynec. 109 (1971) 1011

[11] Krauer, B., P. Spring, L. Detrui: Zur Pharmakokinetik der Sulfonamide im ersten Lebensjahr. Pharmacol. Clin. 1 (1969) 47

[12] Marcucci, F., R. Fanelli, M. Frova, P. L. MorSELLI: Levels of diazepam in adipose tissue in rats, mice and man. Europ. J. Pharmacol. 4 (1968) 464

[13] MrRkn, B. L.: Diphenylhydantoin: placental transport, fetal localization; neonatal metabolism and possible teratogenic effects. J. Pediat. 78 (1971) 329

[14] Nrtowsky, H. M., L. Matz, J. A. Berzofsky: Studies on oxidative drug metabolism in the full-term newborn infant. J. Pediat. 69 (1966) 1139

[15] Owens, J. R., S. F. Irani, A. W. Blarr: Effect of diazepam administered to mothers during labor on temperature regulation of neonate. Arch. Dis. Childh. 47 (1972) 107

[16] Pelkonen, O., P. Arvele, N. T. Kärki: 3,4-Benzpyrene and $\mathrm{N}$-methylaniline metabolizing enzymes in the immature human foetus and placenta. Acta Pharmacol. (Kbh.) 30 (1972) 385

[17] Pelkonen, O., M: Vorne, P. Jouppile, N. T. Karki: Metabolism of chlorpromazine and p-nitrobenzoic acid in the liver, intestine and kidney of the human foetus. Acta Pharmacol. (Kbh.) 29 (1971) 284

[18] Pelkonen, O., M. Vorne, N. T. KärkI: Drugmetabolizing activity in the liver, intestine and kidney of human foetus. Acta physiol. scand. 77, suppl. 330 (1969) 69

[19] Pikkarainen, P. H., N. C. R. Räihä: Development of alcohol dehydrogenase activity in the human liver. Pediat. Res. 1 (1967) 165

[20] Prensky, A. L., M. C. Rafr, M. J. Moore, R. S. SCWAAB: Intravenous diazepam in the treatment of prolonged seizures activity. New Engl. J. Med. 276 (1967) 779

[21] RANe, A., F. SjöQvist: Drug metabolism in the human fetus and newborn infant. Pediat. Clin. N. Amer. 19 (1972) 37

[22] Reinicke, C., G. Rogner, J. Frenzel, B. MaAk, W. KlINGER: Die Wirkung von Phenylbutazon und Phenobarbital auf die Amidopyrin-Elimination, die Bilirubin-Gesamtkonzentration im Serum und einige Blutgerinnungsfaktoren bei neugeborenen Kindern. Pharmacol. Clin. 2 (1970) 167

[23] RoHwedder, H. J., U. Goll: Untersuchungen über die Pharmakokinetic von Gentamycin bei Kindern. Dtsch. med. Wschr. 95 (1970) 1171

[24] Rohwedder, H. J., C. Simon, W. Kübler, M. HoHenauer: Untersuchungen über die Pharmakokinetik von Nalidixinsäure bei Kindern verschiedenen Alters. Z. Kinderheilk. 109 (1970) 124

[25] Schwart, M. A., B. A. Koechlin, E. Postma, S. Palmer, G. Krohl: Metabolism of diazepam in rat, dog and man. J. Pharmacol exp. Ther. 149 (1965) 243

[26] Sereni, F., P. L. Morselli, G. Pardi: Postnatal development of drug metabolism in human infants. In: Bossart, H., J.M. Cruz, A. Huber, L. S. Prod'hom, J.Sistek : Perinatalmedicine, Third European Congress of Perinatal Medicine Lousanne, April 1972. Huber, Bern-Stuttgart-Wien 1973

[27] Sereni, F., L. Perletti, N. Manfredi, A. Marini: Tissue distribution and urinary excretion of a tetracycline derivative in newborn and older infants. J. Pediat. 67 (1965) 299

[28] Sereni, F., L. Perletti, E. Marubini, G. Mars: Pharmacokinetic studies with a long-acting sulfonamide in subjects of different ages. Pediat. Res. 2 (1968) 29

[29] Sereni, F., N. Principi: Developmental pharmacology. Ann. Rev. Pharmacol. 8 (1968) 453

[30] Vest, M. F., R. Rossier: Detoxification in the newborn: the ability of the newborn to form conjugates with glucoronic acid, glycine acetate and glutation. Ann. N. Y. Acad. Sci. 111 (1963) 183

[31] Vest, M. F., R. Salzberg: Conjugation reaction in the newborn infant. The metabolism of para-amino benzoic acid. Arch. Dis. Childh. 40 (1965) 97

[32] Yaffe, S. J., A. Rane, F. SJöQvist, L. O. Boreus, S. OrRenIUS: The presence of a monooxygenase system in human fetal liver microsomes. Life Sci. 9 (1970) 1189

\author{
Dr. P. L. Morselli \\ Istituto di Ricerche Farmacologiche "Mario Negri" \\ Via Eritrea 62 \\ Milano - 20157 Italy
}

